\title{
Reaction of melon genotypes to Rhizoctonia solani
}

\author{
Sami J Michereff'; Domingos EGT Andrade²; Rui Sales Júnior³ \\ ${ }^{1}$ UFRPE-Dep ${ }^{\text {to. }}$ Agronomia, Fitossanidade, Av. Dom Manoel de Medeiros, s/n, 52171-900 Recife-PE; ${ }^{2}$ IPA, EE Itapirema, 55900-000 \\ Goiana-PE; ${ }^{3}$ UFERSA, Dep ${ }^{\text {to. }}$ Ciências Vegetais, C. Postal, 137, 59600-970 Mossoró-RN; sami@ depa.ufrpe.br;
}

\begin{abstract}
The intensive exploration of melon (Cucumis melo L.) crops in the Brazilian Northeast favors the occurrence of root diseases such as the Rhizoctonia canker, caused by Rhizoctonia solani. Twenty melon genotypes were challenged against the pathogen isolates RS9 and RS-10 aiming at selecting those potentially useful for breeding programs and/or integrated disease management. Seeds were planted in infested soil (50 mg of colonized rice grains $\mathrm{kg}^{-1}$ of soil). Disease severity was assessed 15 days after inoculation, by means of a disease scale from 0 to 4 , used later to cluster genotypes in five classes. None of the genotypes presented immune-like reaction to $R$. solani, independent of the pathogen isolate. Disease severity ranged from 6.2 to $85.4 \%$ and from 7.8 to $85.2 \%$, for isolates RS-9 and RS-10, respectively. When both isolates were considered simultaneously, genotypes Sancho, AF-1805, Athenas, AF-682, Torreon, and Galileo were highly resistant. Genotypes Sancho and AF- 1805 had the lowest disease severity levels in relation to isolate RS-9, and genotype Gold Pride, in relation to RS-10. These genotypes differed significantly from the others, within isolates. Therefore, they are potential sources of resistance to $R$. solani and should be considered as a priority planting choice in infested areas.
\end{abstract}

Keywords: Cucumis melo, Rhizoctonia canker, genetic resistance.

\section{RESUMO}

\section{Reação de genótipos de melão a Rhizoctonia solani}

O cultivo intensivo de melão (Cucumis melo L.) no Nordeste brasileiro tem favorecido a ocorrência de doenças radiculares como a rizoctoniose, causada pelo fungo Rhizoctonia solani. Visando selecionar genótipos com potencial de utilização nos programas de melhoramento e/ou no manejo integrado da doença, foram avaliados 20 genótipos de melão, em relação a dois isolados do patógeno (RS-9 e RS-10). As sementes foram plantadas em solo infestado com o patógeno pela incorporação de $50 \mathrm{mg}$ de substrato (grãos de arroz) colonizado $\mathrm{kg}^{-1}$ de solo. A avaliação dos genótipos foi realizada após 15 dias, com o auxílio de escala de notas de 0 a 4, para agrupamento de cada genótipo em cinco classes e cálculo do índice de severidade da doença. Nenhum dos genótipos apresentou reação de imunidade a $R$. solani, independentemente do isolado. Os índices de severidade da doença variaram de 6,2 a $85,4 \%$ e de 7,8 a $85,2 \%$ para os isolados RS-9 e RS-10, respectivamente. Quando considerados os dois isolados do patógeno simultaneamente, os genótipos Sancho, AF-1805, Athenas, AF-682, Torreon e Galileo comportaram-se como altamente resistentes. Os genótipos Sancho e AF-1805 apresentaram os menores índices de severidade da rizoctoniose em relação a RS-9 e, o genótipo Gold Pride, em relação a RS-10. Esses genótipos diferiram significativamente dos demais, considerando cada isolado do patógeno individualmente e, portanto, constituem fontes promissoras de resistência a $R$. Solani, devendo ser preferidos para plantio em áreas infestadas pelo patógeno.

Palavras-chave: Cucumis melo, rizoctoniose, resistência genética.

(Recebido para publicação em 30 de maio de 2007; aceito em 31 de julho de 2008)

$\mathrm{M}$ elon (Cucumis melo L.) is gaining considerable importance in Brazil due mainly to exports. The Northeast region of Brazil, noticeably the states of Rio Grande do Norte and Ceará, is responsible for almost $95 \%$ of the Brazilian melon production (FNP, 2007). The Northeast owns its leadership in melon production to the characteristic high temperatures and high insolation levels in the region, which further fruit contents of soluble solids (Santos et al., 2004).

Diseases rank among the main challenges to the melon agribusiness development. Diseases hamper commercial initiatives for melon production and export, and, therefore, limit investments that would generate capital and jobs (Viana et al., 2001). The intensive melon growing in the Brazilian Northeast favors the occurrence of root diseases (Santos et al., 2000), including the
Rhizoctonia canker, caused by Rhizoctonia solani Kühn (Andrade et al., 2005a,b). The canker symptomatology varies widely. $R$. solani can damage different parts of the plant, causing seed, root, and fruit rot; dumping off, and stem canker. All of these diseases lead either to a premature plant death and/or decrease in yield (Brutton, 1998; Garciá-Jiménez et al., 2000).

$R$. solani control is extremely difficult, taking into account that it is a soil-borne pathogen that combines high saprophytic competitive ability to a wide host range (Blancard et al., 1991; Bruton, 1996). To avoid the disease, farmers often abandon infested areas and migrate to non-infested fields. This practice causes large economic losses, due both to the devaluation of abandoned areas and to the need of re-installing the production infrastructure in the new fields. In this framework, the use of resistant cultivars is a strategic measure in the integrated management of the Rhizoctonia canker.

Despite the relevance of the disease, apparently there are no reports of melon genetic resistance to the Rhizoctonia canker. To start filling the gap, this study assessed the reaction of 20 melon genotypes to $R$. Solani, aiming at subsidizing future melon breeding programs. Concurrently, we intended to select cultivars potentially useful for breeding and for integrated disease management.

\section{MATERIAL AND METHODS}

Resistance evaluation was carried out in a greenhouse, with the air temperature varying between 27 and $35^{\circ} \mathrm{C}$, and air humidity between 68 and $91 \%$, at the Federal Rural University of Pernambuco (UFRPE), in Recife (PE). A collection of 20 commercial melon genotypes was 
challenged against two $R$. solani isolates. The genotype collection included five commercial types: Yellow Valenciano (inodorus group) (genotypes AF-646, AF682, AF-1805, Athenas, Frevo, Gold Mine, Goldex, Gold Pride, Gold Star, PS 2264, Rochedo, RML 5006, and Vereda), Cantaloupe (genotypes Acclaim, Hy-Mark, and Torreon), Galia (Galileo), Piel de Sapo (genotypes PSR 3703001 and Sancho), and non-defined (genotype Trusty LSL).

$R$. solani isolates were obtained from melon plants, type Yellow Valenciano (RS-9) and Galia (RS-10), with symptoms of stem canker, collected at Mossoró and Baraúna (RN), respectively. Isolates were deposited in the Collection of Cultures of Plant Pathogenic Fungi of UFRPE, with codes CFF-1064 (RS-9) and CFF-1069 (RS-10), and were selected for this work based on a preliminary assessment of the pathogen variability (Andrade et al., 2005 b). Inoculum was prepared in autoclaved $\left(120^{\circ} \mathrm{C}, 30 \mathrm{~min} ., 1 \mathrm{~atm}\right)$ Erlenmeyer flasks, containing $50 \mathrm{~g}$ of substrate (rice grains), and $30 \mathrm{~mL}$ of distilled water. The fungus was grown in potato-dextrose-agar medium and, after seven days, three $5 \mathrm{~mm}$ diameter culture discs were transferred to the sterile flasks, which were then kept for ten days in an incubator type BOD, at $25^{\circ} \mathrm{C}$ and constant luminosity. The colonized substrate was placed in paper bags for drying, for 48 hours, at $30^{\circ} \mathrm{C}$ and constant luminosity, also in a BOD. Later, the substrate was ground in a blender for five minutes, and weighted to prepare the aliquots to be incorporated into the soil.

In the experiment, a sandy-clay soil $(\mathrm{pH}$ = 6.5; $\mathrm{N}: 1.005 \mathrm{ppm} ; \mathrm{P}=3 \mathrm{mg} \mathrm{dm}{ }^{-3} ; \mathrm{K}=$ $0.12 \mathrm{cmol} \mathrm{dm}^{-3} ; \mathrm{Al}=1.35 \mathrm{cmol}_{\mathrm{c}} \mathrm{dm}^{-3}$;

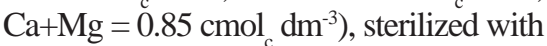
methyl-bromide (Bromex ${ }^{\circ}$ ) was used. The soil was transferred to plastic trays $(30 \mathrm{x}$ $25 \times 4 \mathrm{~cm}, 3 \mathrm{~kg}$ ) 21 days after sterilization and infested with $R$. solani $(50 \mathrm{mg}$ of colonized substrate $\mathrm{kg}^{-1}$ of soil). Melon was sown right after soil infestation, in a density of 25 seeds per tray. Before sowing, seeds were disinfested with $\mathrm{NaClO} 1.5 \%$, for two minutes, rinsed in flow water, and dried for 45 minutes, at $25 \pm 2^{\circ} \mathrm{C}$, in an aseptic chamber. The check treatment corresponded to seeds sown in non-infested soil. The experiment was carried out in a completely randomized design, with five one-tray replications.

Genotypes were daily evaluated for emergency and, 15 days after sowing, disease severity was assessed, using the following scale (Noronha et al., 1995), adapted to melon roots: $0=$ symptomless, $1=$ small lesions on the hypocotyls, $2=$ large lesions on the hypocotyls, but no constriction, 3 = full hypocotyl constriction, showing dumping-off, and 4 $=$ non-emerged seeds and/or plantlets. The average disease severity was calculated for each genotype and used to cluster genotypes in five reaction classes: $0=$ similar to immune (SI); 0.1-1.0 = highly resistant (HR); 1.1-2.0 = moderately resistant (MR); 2.1-3.0 = susceptible (SU); and 3.1-4.0 = highly susceptible (HS). The disease severity index (DSI) in each tray was calculated according to McKinney (1923), using the function: DSI $=[S$ (score in the scale $\mathrm{x}$ frequency)/(total number of units $\mathrm{x}$ maximum score in the scale)] $\mathrm{x}$ 100 , using the data from the disease scale.

DSI values did not fulfill the assumptions of the analysis of variance, i.e. residue normal distribution and variance homogeneity, checked by the Lilliefors and Cochran tests. Therefore, data were transformed into the square root of $x+0.5$, the transformation that resulted in the better data adaptation to the requirements of the analysis of variance. Transformed data were then submitted to the analysis of variance, and genotype means were compared using the Scott-Knott test (pd'0.05). Statistic analyses were performed by SAEG 9.0 (UFV, Viçosa-MG, 2005).

\section{RESULTS AND DISCUSSION}

None of the tested melon genotypes had complete resistance to $R$. solani, independently of the isolate (Table 1). Genotypes Sancho, AF-1805, Athenas, AF682, Torreon, and Galileo were highly resistant to both isolates, while genotypes Acclaim, Gold Star, and RML 5006 were moderately resistant, and genotypes Gold Mine and PSR 3703001 were, respectively, susceptible and highly susceptible. The remaining genotypes showed isolatedependent reactions (Table 1). There was no difference in emergency speed among genotypes. Thus, resistance reactions can not be attributed to a shorter exposure to the pathogen in the soil, which would interfere in genotype response, knowing that $R$. solani acts preferentially over young tissues (Baker \& Martinson, 1970).

Disease severity levels ranged from 6.2 to $85.4 \%$ and from 7.8 to $85.2 \%$ for respectively isolates RS-9 and RS-10. The Scott-Knott cluster analysis revealed five groups of melon genotypes according to the level of Rhizoctonia canker severity (Table 1). The assembling of genotypes in distinct classes of reaction to the disease indicates a genotype differential response to the pathogen isolates, such as previously observed for this pathosystem in other countries (Bruton, 1998; Garcia-Jiménez et al., 1999), and also to other pathosystems in melon (Kobayashi \& Ko, 1985; Sales Júnior et al., 2001; Noronha et al., 2006). Genotypes Sancho and AF1805 had the lowest levels of canker severity for isolate RS-9, while Gold Pride stood out for isolate RS-10. These genotypes differed significantly from the others (pd'0.05) when data within isolates were considered (Table 1). Therefore, they are promising sources of resistance to $R$. solani and should be a preferential choice for growing melon in infested areas. On the contrary, genotype PSR 3703001 was highly susceptible to both $R$. solani isolates, significantly differing from all other genotypes (Table 1).

Among the five most planted genotypes in the agripoles of Mossoró/Assu (RN) and Baixo Jaguaribe (CE), which accounts for nearly $80 \%$ of the total area used for melon production in Brazil (Nunes et al., 2004), three displayed good resistance to $R$. Solani, namely AF-646, AF-682, and Gold Pride, while the remaining top-planted genotypes, Gold Mine and Rochedo, were susceptible to at least one of the studied isolates. It indicates that there is room to the integrated management of the Rhizoctonia canker by means of using commercial resistant genotypes. In disease outbreaks, boosted by the use of infested fields, losses can turn out to be much higher if genotypes do not have a reasonable level of resistance to the pathogen.

The three most promising sources of resistance identified in this work should be included in further investigation concerning the stability of resistance against several other isolates, with different inoculum concentrations, as well as resistance inheritance. It is important to highlight that resistance alone has not been enough to fight root diseases in melon (Bruton, 1998). It is necessary to integrate complementary management strategies to maximize resistance durability. Among these strategies, field and crop rotation, as well as the destruction of crop remains, can be very effective. 


\section{ACKNOWLEGMENTS}

Authors thank CNPq (National Council for Research and Development) for sponsoring this work (process no. 620111/04-6), and Seminis Vegetable Seeds, Rogers Seeds, and Agroflora/ Sakata Sudamerica, for making seeds available. Sami J Michereff and Rui Sales Júnior were granted CNPq fellowships for Productivity in Research.

\section{REFERENCES}

ANDRADE DEGT; MICHEREFF SJ; BIONDI CM; NASCIMENTO CWA; SALES JÚNIOR R. 2005a. Frequiência de fungos associados ao colapso do meloeiro e relação com características físicas, químicas e microbiológicas dos solos. Summa Phytopathologica 31: 327-333.

ANDRADE DEGT; SILVA CFB; SILVA LGC; MICHEREFF SJ; SALES JÚNIOR R; ASSIS TC. 2005b. Influência da densidade do inóculo e de isolados de Rhizoctonia solani na severidade da rizoctoniose do meloeiro. Caatinga 18: 164-168.

BAKER R; MARTINSONCA. 1970. Epidemiology of diseases caused by Rhizoctonia solani. In: PARMETER JR (ed). Rhizoctonia solani, biology and pathology. Berkeley: The University of California Press. p. 172-188.

BLANCARD D; LECOQ H; PITRAT M. 1991. Enfermedades de las cucurbitaceas. Madrid: Mundi-Prensa. 301p.

BRUTON BD. 1996. Crater rot. In: ZITTER TA; HOPKINS DL; THOMAS CE(eds). Compendium of cucurbit diseases. St. Paul: APS Press. p. 49-50.

BRUTON BD. 1998. Soilborne diseases in cucurbitaceae: pathogen virulence and host resistance. In: MCCREIGHT J (ed). Cucurbitaceae'98. Alexandria: International Society for Horticultural Science. p. 143-166.

FNP. 2007. Agrianual 2007 - Anuário da agricultura brasileira. São Paulo: Instituto FNP. 532p.

GARCIÁ-JIMÉNEZ J; ARMENGOL J; SALES JÚNIOR R; JORDÁ C; BRUTON BD. 2000. Fungal pathogens associated with melon plants collapse in Spain. EPPO Bulletin 30: 169-173.

GARCIÁ-JIMÉNEZ J; MOYA MJ; ARMENGOL J; SALES JÚNIOR R; MIGUEL C; GARCIAMORATO M;PARDOA. 1999. La podredumbre del cuello y frutos de la calabaza: una enfermedad potencialmente grave para el cultivo de cucurbitáceas en España. Phytoma 107: 17-20.

KOBAYASHI N; KO WH. 1985. Nature of suppression of Rhizoctonia solani in Hawaiian soils. Transactions of the British Mycological Society 84: 691-694.

McKINNEY HH. 1923. Influence of soil temperature and moisture on infection of wheat seedlings by Helminthosporium sativum. Journal of A gricultural Research 26: 195-218.

NORONHA MA; MICHEREFF SJ; MARIANO RLR. 1995. Efeito do tratamento de sementes de caupi com Bacillus subtilis no controle de Rhizoctonia solani. Fitopatologia Brasileira 20: 174-178.

NORONHA MA; MICHEREFF SJ; XAVIER FILHA MS; MOREIRA PAA; REIS A; SALES JÚNIOR R. 2006. Reação de genótipos de meloeiro a Myrothecium roridum. Horticultura Brasileira 24: 495-498.

Table 1. Reaction of melon genotypes to two Rhizoctonia solani isolates in greenhouse (reação de genótipos de melão a dois isolados de Rhizoctonia solani sob condições de casade-vegetação). Recife, UFRPE, 2006.

\begin{tabular}{|c|c|c|c|c|c|c|c|}
\hline \multirow{3}{*}{ Genotype } & \multirow{3}{*}{ Group ${ }^{1}$} & \multicolumn{3}{|c|}{ Isolate RS-9 } & \multicolumn{3}{|c|}{ Isolado RS-10 } \\
\hline & & \multicolumn{2}{|c|}{ Disease class } & \multirow{2}{*}{$\begin{array}{c}\text { Severity } \\
(\%)^{4}\end{array}$} & \multicolumn{2}{|c|}{ Disease class } & \multirow{2}{*}{$\begin{array}{c}\text { Severity } \\
(\%)\end{array}$} \\
\hline & & Average $^{2}$ & Reaction $^{3}$ & & Average & Reaction & \\
\hline PSR 3703001 & PS & 3,4 & $\mathrm{HS}$ & $85,4 a^{5}$ & 3,4 & $\mathrm{HS}$ & $85,2 a^{5}$ \\
\hline Gold Mine & $\mathrm{YV}$ & 2,7 & SU & 66,6 b & 2,2 & SU & 55,6 b \\
\hline PS 2264 & $\mathrm{YV}$ & 2,4 & SU & $59,3 b$ & 1,9 & MR & $46,9 \mathrm{~b}$ \\
\hline Hy-Mark & $\mathrm{CA}$ & 2,1 & SU & $53,1 \mathrm{~b}$ & 1,8 & MR & $46,1 \mathrm{~b}$ \\
\hline Rochedo & $\mathrm{YV}$ & 2,1 & SU & $53,1 \mathrm{~b}$ & 1,7 & MR & $42,2 b$ \\
\hline RML 5006 & $\mathrm{YV}$ & 1,6 & MR & $38,1 \mathrm{c}$ & 1,2 & MR & $28,8 \mathrm{c}$ \\
\hline Gold Star & $\mathrm{YV}$ & 1,4 & MR & $36,8 \mathrm{c}$ & 1,7 & MR & $41,3 b$ \\
\hline Acclaim & $\mathrm{CA}$ & 1,4 & MR & $35,4 \mathrm{c}$ & 1,9 & MR & $47,9 \mathrm{~b}$ \\
\hline Gold Pride & $\mathrm{YV}$ & 1,3 & MR & $32,8 \mathrm{c}$ & 0,3 & HR & $7,8 \mathrm{e}$ \\
\hline Vereda & $\mathrm{YV}$ & 1,2 & MR & $29,4 \mathrm{c}$ & 0,9 & HR & $21,4 d$ \\
\hline Galileo & GA & 1,0 & $\mathrm{HR}$ & $25,0 \mathrm{~d}$ & 0,6 & HR & $14,4 d$ \\
\hline Goldex & VA & 1,0 & $\mathrm{HR}$ & $23,7 \mathrm{~d}$ & 1,4 & MR & $35,0 \mathrm{c}$ \\
\hline Trusty LSL & ND & 0,9 & HR & $23,1 d$ & 1,1 & MR & $27,5 \mathrm{c}$ \\
\hline Torreon & $\mathrm{CA}$ & 0,9 & HR & $22,6 \mathrm{~d}$ & 0,5 & HR & $13,3 \mathrm{~d}$ \\
\hline AF-682 & $\mathrm{YV}$ & 0,9 & HR & $21,4 d$ & 1,0 & HR & $24,1 \mathrm{c}$ \\
\hline Athenas & $\mathrm{YV}$ & 0,8 & $\mathrm{HR}$ & $19,6 \mathrm{~d}$ & 1,0 & HR & $24,1 \mathrm{c}$ \\
\hline AF-646 & $\mathrm{YV}$ & 0,8 & HR & $19,5 \mathrm{~d}$ & 1,1 & MR & $27,3 \mathrm{c}$ \\
\hline Frevo & $\mathrm{YV}$ & 0,8 & HR & $18,7 \mathrm{~d}$ & 1,1 & MR & $25,9 \mathrm{c}$ \\
\hline AF-1805 & $\mathrm{YV}$ & 0,5 & HR & $11,7 \mathrm{e}$ & 0,9 & HR & $21,9 d$ \\
\hline Sancho & PS & 0,3 & HR & $6,2 \mathrm{e}$ & 0,7 & $\mathrm{HR}$ & $17,2 \mathrm{~d}$ \\
\hline CV\% & & & & 12,6 & & & 17,3 \\
\hline
\end{tabular}

${ }^{1 / C o m m e r c i a l ~ g r o u p ~(g r u p o ~ c o m e r c i a l): ~ Y V ~=~ Y e l l o w ~ V a l e n c i a n o ~(V a l e n c i a n o ~ A m a r e l o) ; ~}$ $\mathrm{CA}=$ Cantaloupe; GA=Galia; PS=Piel de Sapo (Pele de Sapo); ND=non-defined (Indefinido); ${ }^{2 l}$ Disease reaction class according to the disease scale from 0 to 4 (Noronha et al., 1995), adapted to melon roots, where: $0=$ symptomless, $1=$ small lesions on the hypocotyls, $2=$ small large lesions on the hypocotyls, but no constriction, $3=$ full hypocotyl constriction, showing dumping-off, and 4=non-emerged seeds and/or plantlets (Classe de reação da doença conforme escala diagramática de notas de 0 a 4 (Noronha et al., 1995), adaptada para as raízes de melão, onde: $0=$ sem sintomas; 1=hipocótilo com pequenas lesões; 2 =hipocótilo com grandes lesões, sem constrição; 3=hipocótilo totalmente constrito, mostrando tombamento; e 4=sementes não germinadas e/ou plântulas não emergidas); ${ }^{3 /}$ Disease reaction classes, where: $0=$ similar to immune (SI); $0.1-1.0=$ highly resistant $(\mathrm{HR}) ; 1.1-2.0=$ moderately resistant (MR); 2.1-3.0 = susceptible (SU); and 3.1-4.0 = highly susceptible (classes de reação à doença, onde: $0=$ semelhante à imune $(\mathrm{SI}) ; 0,1-1,0=$ altamente resistente (HR); 1,1-2,0 = medianamente resistente (MR); 2,1-3,0 = suscetível (SU); 3,1-4,0 = altamente suscetível (HS); ${ }^{4}$ Disease severity calculated using the McKinney (1923) index and the frequency of disease classes according to the disease scale from 0 to 4 (severidade da doença, calculada pelo índice de MckKinney (1923), com a utilização das freqüências de classes de doença considerando escala de notas de a 0 a 4 ); ${ }^{5 /}$ Average of five replications. For analysis, data were transformed into $\sqrt{x+0.5}$. Means followed by the same letter in the column did not differ from each other, Scott-Knott test, pd"0.05 (média de cinco repetições. Para análise, os dados foram transformados para $\sqrt{x+0.5}$. Médias seguidas pela mesma letra na coluna não diferem significativamente entre si pelo teste de Scott-Knott, pd"0,05).

NUNES GHS; SANTOS JÚNIOR JJ; ANDRADE FV; BEZERRA NETO F; ALMEIDA AHB; MEDEIROS DC. 2004. Aspectos produtivos e de qualidade de híbridos de melão cultivados no agropólo Mossoró-Assu. Horticultura Brasileira 22: 744-747.

SALES JÚNIOR R; VICENT A; ARMENGOL J; GARCÍA-JIMÉNEZ J; KOBORI RF. 2001. Comportamento de cultivares de meloeiro e melancia inoculados com Acremonium cucurbitacearum e Monosporascus cannonballus. Fitopatologia Brasileira 27: 206-210.

SANTOS AA; CRISÓSTOMO JR; CARDOSO JW. 2004. Avaliação de híbridos de melão quanto às principais doenças nos Estados do Ceará e Rio Grande do Norte. Fortaleza: Embrapa Agroindústria Tropical. 14p.
SANTOS AA; FREIRE FCO; LIMA JAA; CARDOSO JE. 2000. Doenças do meloeiro em áreas irrigadas no Estado do Ceará. Fortaleza: Embrapa Agroindústria Tropical. 11p.

VIANA FMP; SANTOS AA; FREIRE FCO; CARDOSO JE; VIDAL JC. 2001. Recomendações para o controle das principais doenças que afetam a cultura do melão na região Nordeste. Fortaleza: Embrapa Agroindústria Tropical. 22p. 